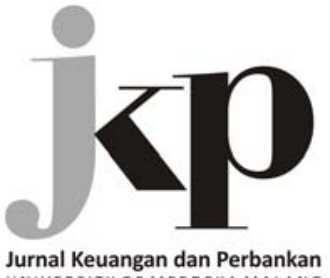
Jurnal Keuangan dan Perbankan
UNIVERSITY OF MERDEKA MALANG

Article history:

Received: 2018-03-01

Revised: 2018-06-02

Accepted: 2018-09-15

Yetty Murni, Tri Astuti, Chaerani Nisa

Department of Management, Faculty of Economics and Business, Pancasila University Jl. Raya Lenteng Agung, Jakarta Selatan, 12640, Indonesia

$\triangle$ Corresponding Author:

Chaerani Nisa:

Tel +62 217864727

E-mail: chaerani.nisa@univpancasila.ac.id

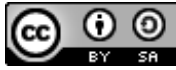

This is an open access article under the CC-BY-SA license

\author{
Yetty Murni (Indonesia), Tri Astuti (Indonesia), \\ Chaerani Nisa (Indonesia)
}

\section{Determinants of Profit Sharing Financing and Zakat Distribution Based on CAMEL Analysis}

\begin{abstract}
The rapid development of Islamic banking has many positive impacts, but on the other hand, the development also demands the readiness of sharia banking in meeting the soundness level standard set by the regulator. This study aimed to integrate the two methods of measurement of Islamic financial institutions, the CAMEL method and maqasidsharia method. How far the ability of CAMEL, macro and general measurement, in measuring the variables on the maqasid sharia. This research used panel data model and analyzed four regressions model which welfare model for Sharia Commercial Bank and Sharia Business Unit and affordable product model for Sharia Commercial Bank and Sharia Business Unit. This research used the quantitative descriptive method. We found that only affordable product in Sharia Business Unit can explain independent variable. Other than that, earning component in CAMEL (ROA) had a positive and significant relationship with profit sharing scheme loan. From the results of research conducted, in general, CAMEL and maqasid sharia did not have a relationship except for Sharia Business Unit. This condition can happen because of many things. Among the greater was risks and in terms of better profitability. Therefore, Sharia Commercial Bank and Sharia Business Unit, generally still run a relatively low-risk financing scheme such as murabahah.
\end{abstract}

Keywords: Bank Soundness Level; CAMEL; Maqasid Sharia; Profit Sharing Financing

JEL Classification: G31, G32, G34

Citation: Murni, Y., Astuti, T., \& Nisa, C. (2018). Determinants of profit sharing financing and zakat distribution based on CAMEL Analysis. Jurnal Keuangan dan Perbankan, 22(4), 760-768. https:// doi.org/10.26905/jkdp.v22i4.2402

\begin{abstract}
Abstrak
Pesatnya perkembangan perbankan syariah memiliki banyak dampak positif, tetapi di sisi lain, perkembangan juga menuntut kesiapan perbankan syariah dalam memenuhi standar tingkat kesehatan yang ditetapkan oleh regulator. Penelitian ini bertujuan untuk mengintegrasikan dua metode pengukuran lembaga keuangan syariah yaitu metode CAMEL dan metode maqasid syariah. Seberapa jauh kemampuan CAMEL, sebagai alat ukur yang sifatnya makro dan general, dalam mengukur variabel pada maqasid syariah. Penelitian mengounakan metode panel data dan menganalisis empat model regresi. Keempat model regresi tersebut adalah model kesejahteraan umat yang diregresi untuk Bank Umum Syariah (BUS) dan Unit Usaha Syariah (UUS). Model kedua adalah model produk dengan harga terjangkau yang juga diregresi pada BUS dan UUS. Penelitian menggunakan metode kuantitatif deskriptif. Kami menemukan bahwa hanya model produk yang bisa memberikan harga terjangkau saja yang memiliki kemampuan dalam menjelaskan variabel dependen. Selain itu,komponen variabel earning dalam CAMEL berhubungan positif dan signifikan terhadap besarnya pembiayaan bagi hasil. Dari hasil penelitian yang dilakukan, pada umumnya BUS dan UUS yang beroperasi baik menurut CAMEL belum menjalankan fungsi maqasid syariah dengan baik. Kondisi ini bisa terjadi karena banyak hal. Diantaranya risiko yang lebih besar dan dari sisi rentabilitas yang lebih baik. Karena itu, BUS dan UUS pada umumnya masih menjalankan metode pembiayaan yang relatif rendah risiko seperti murabahah.
\end{abstract}

Kata Kunci: Tingkat Kesehatan Bank; CAMEL; Maqasid Syariah; Pembiayaan Bagi Hasil 


\section{Determinants of Profit Sharing Financing and Zakat Distribution Based on CAMEL Analysis}

Yetty Murni, Tri Astuti, \& Chaerani Nisa

Sharia-based finance industry currently has a significant position in the world financial industry. Various financial products appear in the last two decades. The presence of sharia financial product provides an alternative to meet the people's need for good financial products. Qualified not only in terms of providing benefits and secure products but also brings blessing, because the main principle in Islamic finance is that business must be brought goodness and lawful in every stage of the process

One of the fastest growing sharia financial industry is the sharia banking. It started twenty years ago, nowadays Indonesia sharia banking has gained a lot of achievements, both from the aspects of institutions and supporting infrastructure, regulatory and supervisory systems, as well as awareness and public literacy towards sharia financial services. The Islamic financial system in Indonesia has become one of the most complete recognized systems. Which means it covers almost all the basic Muslims need for banking product. As of November 2017, the sharia banking industry consists of 13 sharia commercial banks (SCB), 22 sharia business units (SBU) owned by conventional commercial banks (CCB) and 167 BPRS with total assets of IDR278,005 trillion with 3.8 percent market share.

On the one hand, the rapid development of Islamic banking has many positive impacts, but on the other hand, the development also demands the readiness of sharia banking in meeting the soundness level standard set by the regulator. Banking soundness level itself is a measurement related to banking condition. The level of banking soundness is measured by a method called CAMEL.

CAMEL method measures capital owned by banks, asset quality, management, profitability, and bank liquidity level. CAMEL is used as a measurement of sharia banking soundness level since 2008. In 2014, the Financial Services Authority (OJK) updated the measurement of sharia soundness level by launching RGEC. At RGEC, the soundness level is more focused on measuring the risk profile faced by banks, corporate governance, profitability, and capital.

Current measurement of sharia bank soundness level, based largely on conventional soundness level and rules, has previously been widely used by conventional banks and sharia financial institutions (Sarker, 2006). Although these measurements can accurately see the extent to which risks can be faced by sharia banks, however, the full and adequate use of sharia rules is still required. Various proposals related to measurement that are more advanced conformity between the rules in Islam with the conventional rules have been given by many researchers. Triyuwono (2011) among others propose an alternative measurement of sharia bank soundness level. He suggested the use of ANGELS method where the focus measurement not only on results but also on processes and stakeholders.

The use of CAMEL in measuring the soundness of Syariah bank is appropriate, but it is necessary to adjust the risks faced by sharia banks, mainly related to compliance with sharia rules, capital adequacy, asset quality, and liquidity (Mejia et al., 2014). This condition arises because Islamic banks have a unique risk character. In accordance with the rules in sharia banking, the products offered should not violate the provisions in Islam. For financing, as an example, products with the profit-sharing system is more relevant and more in accordance with sharia, but this financing system requires high monitoring costs. As a result, there is a decrease in expected future profits, so that Islamic banks tend to disburse riskier loan to increase profit (Basher, Kessler, \& Munkin, 2017).

In line with the initial goal of the establishment, sharia banks are that financial institutions which are able to implement banking practices based on the concept of sharia and in accordance with the teachings of Islam. Those are staying away from what is forbidden and put the common interest first. The second function is known as Tayib or good. In line with the Tayib principle, the sharia bank must 
prioritize the social function in its activities. A function where the benefit of the people can be achieved. To achieve that goal, Imam Abu Hamid Al-Ghozali revealed five aspects must be met. These five aspects are faith (din), soul (nafs), the reason ('aql), descent (nash), and property (mall). Whatever guarantees the protection of these five cases is to fulfill the public interest and is encouraged, and whatever hurts these five cases is against the public interest that should be discarded (Chapra, 2011).

Some conditions that reflect the creation of Tayib functions by Islamic banks are the level of zakat distribution and financing composition with the profit-sharing scheme. About this, this study aims to examine in depth how the components of the level of bank health in determining the collection and distribution of zakat. As well as how the components in CAMEL are in determining the amount of financing with the profit-sharing scheme.

Sharia bank level of soundness was first introduced in 2007 with PBI no. 9/1/PBI/2017. According to this regulation, bank soundness is the result of qualitative assessment on various aspects affecting the condition or performance of a bank for SBU through quantitative assessment and qualitative assessment of capital, asset quality, profitability, liquidity, market risk sensitivity, and qualitative assessment of management factors (Bank Indonesia, 2007). This PBI is the first regulation that measures sharia bank soundness level. Before this PBI, sharia bank soundness level measurement was based on conventional bank soundness level.

In 2014, OJK issued the latest regulation concerning the measurement of banks soundness level. In POJK No. 8/POJK.03/2014 mentioned that bank soundness level is the result of bank valuation. This valuation includes the fulfillment of sharia requirement and bank risk performance which is called riskbased bank rating. This regulation emphasizes the eight risks that banks potentially face, how they handle it and what has been done by the bank to mitigate the risk. In addition, in contrast to the previous rules, in the latest rules, the bank is also required to conduct self-assessment. Self-assessment is done at least twice a year for the positions of June and December.

Unlike the measurements using CAMEL or RGEC where the test used is also used to see the soundness level in conventional banks, sharia financial institutions have their performance calculation called maqasid sharia. Maqasid sharia sees and measures the performance of a financial institution from its manifestation to all people. The concept of maqasid shariah departs from the understanding of the obligation for the sharia bank in addition to fulfilling the purpose to gain profit but also perform its function as a sharia entity based on the maqasid sharia. Maqasid sharia becomes a reference and guidance for sharia banks in carrying out their activities (Afrinaldi, 2014). Measurement of maqasid sharia is divided into three categories which are Tahdhib al-Fard (Individual Education), Iqamah al'adl (Formation of Justice), and Jalb al-Maslahah (Public Interest) (Adzhani \& Rini, 2017).

The education category describes the efforts made by sharia banks in spreading thoughts about sharia through promotional efforts and the development of products and services it provides. In addition, sharia banks are also required always to improve their employees' ability in the form of training to develop their skills. In addition, the educational performance is measured by how much funds the bank spends on income earned for use as a scholarship to the surrounding community.

The next measurement is in the category of justice. This condition includes a fair service to all parties without discriminating customers. In addition, between the bank and the customer must be established a mutually beneficial relationship and does not harm one party, because the relationship between the bank with the customer is a parallel relationship (Sutrisno, 2017). One element in the measurement of this category is how much financ- 


\section{Determinants of Profit Sharing Financing and Zakat Distribution Based on CAMEL Analysis}

Yetty Murni, Tri Astuti, \& Chaerani Nisa

ing is done using Musharaka and Mudaraba methods. The amount of financing by these methods illustrates the spirit of the bank to run the true concept of maqasid shariah (Mohammed, Tarique, \& Islam, 2015) because it shows the bank participate in the running of social and economic justice (Antonio, Sanrego, \& Taufiq, 2012).

Measurement of sharia maqasid used in this study refers to the concept of measurement by Mohammed \& Razak (2008). The concept was later modified by Antonio, Sanrego, \& Taufiq (2012). The weight of each element and objective is formulated by Islamic finance experts in the Middle East and Malaysia. From each of these objectives, there are ten elements that are divided into four elements for education, three elements for justice and three elements for measuring the performance of the fulfillment of public needs (Antonio, Sanrego, \& Taufiq, 2012). Each element is a ratio and on each element is given weight. Similarly, at each goal measurement, weights are given at each measured goal.

Sarker (2006) proposed additional variables in measuring the soundness of Islamic banks. The addition is done because CAMELS has not been able to measure accurately how the rules of sharia applied to the daily bank operations. Therefore, to capture the existence of these rules, Sarker suggested the need for the addition of sharia matrix variables. In this variable, Sarker suggests a field used to evaluate how the application of the sharia method to the liabilities side of the bank.

In research conducted by Triyuwono (2011) proposed the measurement of the soundness of Islamic banks based on the ANGELS approach. ANGELS stands for Amanah management, Non-economic wealth, Give out, Earnings, Capital and assets, Liquidity and Sensitivity to market, and Socioeconomic wealth. In this measurement, researchers try to propose a new method in which the results are not the only factors assessed. However, the existence of process elements and impacts on stakeholders is also considered here.
Every action undertaken by sharia entities, especially sharia banking must be based on the teachings of Islam. Thus, it becomes essential to understand the purpose of sharia (maqasid sharia) in order to produce creativity, flexibility, and ability to adapt to the conditions of society (Afrinaldi, 2014). Performance measurement using maqasid sharia index is also done by Abdillah (2014) and Dusuki \& Abdullah (2015).

Meanwhile, CAMEL itself is used by sharia banking and conventional banking to measure their soundness level. Based on CAMEL measurement, we can find out the bank's quality. This measurement is used until 2014. After that, it changes into RGEC measurement. Erol et al. (2014) use CAMEL to compare commercial and Islamic bank's performance in Turkey. It shows that Islamic banks performed better in terms of profitability and asset quality.

This research integrates CAMEL variable as an independent variable while an indicator of maqasid sharia variable as the dependent variable. Pradesyah (2017) analyzed the determinants of profit sharing financing. The result of his research shows that problem loans have a positive effect on mudaraba financing. Meanwhile, Yulianto \& Solikhah (2016) found that effectiveness of sharia supervisory board, obedience to sharia law and NPL level has support for-profit loss sharing scheme in six sharia banks.

\section{METHODS}

In this study, the measurement used is a category of justice and public interest. Variable selection based on consistency on website (www.ojk. go.id). The category of justice itself consists of the dimensions of fair returns, products, and services that people reach and the elimination of injustice. In the study, the dimensions of affordable products and services are used to represent bank performance based on maqasid sharia. 
Profit Sharing $(P S)=\frac{\text { mudharabah and musyarakah }}{\text { total financing }}$

Meanwhile, the second variable in maqasid sharia that we used is a variable that represents the ability of sharia banks to increase people welfare. The formula is:

Zakat Ratio $=\frac{\text { zakat paid }}{\text { net income }}$

In the CAMEL component, the components included in the analysis are only capital components, asset quality, profitability, and liquidity capability. While the management component itself is not included, for the capital, we use capital adequacy ratio (CAR) variable, non-performing finance (NPF) ratio for asset quality component, return on asset (ROA) for earning capacity, and quick ratio for liquidity component.

Based on that, we propose a model to see the relationship between those two factors. We use panel least square since our data is panel data. The models are:

$Z R_{i, t}=\alpha+\beta_{1} C A R_{i, t}+\beta_{2} N P F_{i, t}+\beta_{3} R O A_{i, t}+\beta_{4} Q R_{i, t}$

Equation (3) is for the welfare model.

$P S_{i, t}=\beta_{1} C A R_{i, t}+\beta_{2} N P F_{i, t}+\beta_{3} R O A_{i, t}+\beta_{4} Q R_{i, t}$ Equation (4) is for the affordable product model.

Based on the above explanation, our hypothesis is CAEL performance has a positive relationship with profit sharing and zakat ratio. Which means, banks with good CAEL performance also have high-profit sharing ratio and zakat ratio. Since sharia bank with good CAMEL performance, ideally should have good sharia performance.

In order to analyze the data, we use a panel model. To choose the best panel model, some test must be applied. Those tests are Chow test, Lagrange multiplier, and Hausman test (Yudaruddin, 2017). Those tests are using to choose between common effect model, fixed effect model, and random effect model.

Population in this research is the entire sharia bank, whether it is commercial or business unit, in Indonesia. While for the sample, we used purposive sampling method based on data availability.

The total data used are secondary data collected from the published report of SCB and SBU. This publication report is gathered from website (www.ojk.go.id). We use criteria that SCB and SBU must have complete data. The data are from 20102016 for SCB, while for SBU is from 2015-2016. All the data are annual. Based on those criteria, we got 11 sharia commercial banks and 17 sharia business units.

\section{RESULTS}

Based on that explanation, we regress four equation. Those are the welfare model for SCB and SBU and affordable product model for SCB and SBU. For Welfare model, the best model is a random effect model for SCB and SBU. Meanwhile, for an affordable product model, the best model is a random effect model for SCB and fixed effect model for SBU.

Table 2 until 5 demonstrate results that we got. For SBU, we do not use CAR variable because they do not have it. Table 4 and Table 5 show welfare and affordable product model in SBU.

Table 2 shows the welfare model in SCB. It shows that CAR, NPF, ROA, and Quick ratio do not have any significant effect in zakat ratio. The $R$ Squared also give the low result. It means independent variable only able to explain 1.3 percent of the movement an independent variable.

Meanwhile, in Table 3, there's an increase in $\mathrm{R}$ Squared through the F Stat is still not significant. Other than that, CAR has a negative significant impact in profit sharing scheme loan. 


\section{Determinants of Profit Sharing Financing and Zakat Distribution Based on CAMEL Analysis}

Yetty Murni, Tri Astuti, \& Chaerani Nisa

In Table 4, the ability of independent variables in explaining dependent variable only 8 percent. ROA, NPF, and quick ratio do not have any significant effect in zakat ratio.
In Table 5, it shown that only this regression equation has the ability to explain the model quite well. In this model, R squared is 96.3 percent with the probability value for $\mathrm{F}$ stat is 0.0000 . It means

Table 1. Definitions of Variables

\begin{tabular}{|c|c|c|c|}
\hline Variables & Classifiaction & Description & Source \\
\hline $\mathrm{ZR}_{\mathrm{i}, \mathrm{t}}$ & Welfare Model & $\begin{array}{l}\text { Total zakat amount divided by net } \\
\text { incomes }\end{array}$ & Financial Services Authority \\
\hline Profit Sharing & $\begin{array}{l}\text { Affordable Product } \\
\text { Model }\end{array}$ & $\begin{array}{l}\text { Total amount loan with profit sharing } \\
\text { method (mudaraba and musharaka) } \\
\text { divided by total loan }\end{array}$ & Financial Services Authority \\
\hline CAR & Capital & Capital Adequacy Ratio & Financial Services Authority \\
\hline NPF & Asset Quality & Non-Performing Finance & Financial Services Authority \\
\hline $\mathrm{ROA}$ & Earning & Return on asset & Financial Services Authority \\
\hline Quick ratio & Liquidity & $\begin{array}{l}\text { Liquid asset divided by short-term } \\
\text { liability }\end{array}$ & Financial Services Authority \\
\hline
\end{tabular}

Source: Financial Services Authority (2017)

Table 2. Estimation result for Welfare Model (Sharia Commercial Bank)

\begin{tabular}{lcrr}
\hline \multicolumn{1}{c}{ Dependent Variable } & Independent Variable & Coefficient & t-Statistic \\
\hline & Constanta & 0.011914 & 1.520240 \\
ZR & CAR & -0.006291 & -0.477065 \\
& NPF & 0.058276 & 0.662601 \\
& ROA & -0.004006 & -0.308456 \\
R Squared & Quickratio & 0.001011 & 0.150602 \\
Adjusted R Squared & & & \\
F Statistic & & 0.013173 & \\
Prob (F-Statistic) & -0.041650 & & \\
\hline
\end{tabular}

Table 3. Estimation Result for Affordable Product Model (Sharia Commercial Bank)

\begin{tabular}{lccl}
\hline \multicolumn{1}{c}{ Dependent Variable } & Independent Variable & Coefficient & t-Statistic \\
\hline & Constanta & 0.367541 & 5.021605 \\
Profit Sharing Method & CAR & -0.178438 & $-1.999053^{* *}$ \\
& NPF & 0.108937 & 0.187781 \\
& ROA & 0.078763 & 0.927789 \\
& Quickratio & 0.020209 & 0.453439 \\
R Squared & & \\
Adjusted R Squared & 0.085726 & \\
F Statistic & 0.034933 & \\
Prob (F-Statistic) & 1.687757 & \\
\hline
\end{tabular}

** Significance in 5 percent 
variation independent variable which can be explained by indpendent variable is 96 percent. While the model also feasible since the probability value is 0.000 . In terms of independent variable, ROA has a significant positive relation with profit sharing method in SBU. It means, the higher the profit in SBU, the higher profit sharing scheme that SBU give to their customer (debtor).

\section{DISCUSSION}

Based on this research, CAEL does not have any relationship in profit sharing and zakat distribution. This condition happens in sharia commercial bank. Meanwhile in sharia business unit, only in affordable product (profit sharing) model, CAEL have a close relationship. It implies that there's no relationship between CAEL (conventional banking) performance and sharia performance.
Ratnaputri (2013) investigate the relationship between CAMEL performance and sharia conformity and profitability model. In this research, it was found that only one bank has good performance in both categories. A similar result was found by Rusydiana \& Parisi (2016). Only one sharia commercial bank has a relatively good position in both definitions, maqasid sharia and profitability while Afrinaldi (2014) found only two banks, from 5 banks as an object, which has good performance in both situation.

This condition also reflected in similar research in another area. Hamza (2015) found that profit loss sharing in sixty banks in Asia influenced by a moral hazard behavior and excessive risk-taking. While most countries in MENA (the Middle East and North Africa) show that most of their profit in profit loss scheme is determined based on risk aversion, inefficiency, diversification, and economic condition (Bougatef \& Korbi, 2018).

Table 4. Estimation Result for Welfare Model (Sharia Business Unit)

\begin{tabular}{lcrrr}
\hline \multicolumn{1}{c}{ Dependent Variable } & Independent Variable & Coefficient & t-Statistic \\
\hline & Constanta & 0.017143 & 0.8288 \\
ZR & NPF & 1.018738 & 0.2912 \\
& ROA & -0.438800 & 0.7937 \\
\multicolumn{1}{l}{ Quickratio } & & -0.027229 & 0.7739 \\
R Squared & & & \\
Adjusted R Squared & & 0.080824 & & \\
F Statistic & & -0.011094 & & \\
Prob (F-Statistic) & & 0.879307 & & \\
\hline
\end{tabular}

Table 5. Estimation Result for Affordable Product Model (Sharia Business Unit)

\begin{tabular}{lcrrr}
\hline \multicolumn{1}{c}{ Dependent Variable } & Independent Variable & Coefficient & t-Statistic \\
\hline & Constanta & 0.092823 & 0.999443 \\
ZR & NPF & 1.879670 & 1.187709 \\
& ROA & 6.244278 & $2.707092^{* *}$ \\
R Squared & Quickratio & & -0.029468 & -0.283498 \\
Adjusted R Squared & & & & \\
F Statistic & & 0.963309 & & \\
Prob (F-Statistic) & & 0.913515 & & \\
\hline
\end{tabular}

**Significant in 5 percent level 
As we can see from that reserach, all of the research found that no significant relation between those categories. In this research, these conditions also happen. The difference is in research objects. While most of the research use sharia commercial bank, this research also uses sharia business unit. This condition is strengthened by the fact that sharia banking does not promote profit loss sharing schemes such as mudaharah or musharaka. Alternatively, they still use murabahah as a dominant scheme (Minhat \& Dzolkarnaini, 2016).

In SCB, CAR has a negative significant impact on profit sharing scheme. It means, the higher the CAR, the lower profit sharing scheme that $S C B$ gives to their customer. It might be related to SCB policy since most of the low risk loan is in nonprofit sharing scheme.

In SBU, independent variables can explain dependent variable. One independent variable, which is ROA, has a significant effect on profit sharing product. It shows quite difference result with Sutrisno (2017). It said that SBU with high-profit sharing scheme financing has lower ability to generate earnings. Since the profit sharing scheme needs closer monitoring. Hence, this effect SCB ability to make a profit. While in this research, the opposite thing happen.

\section{CONCLUSION AND SUGGESTIONS}

\section{Conclusion}

This research finds that CAEL does not have any relationship with maqasid shariah index, whether for profit sharing or zakat ratio. The relationship only exists on sharia business unit. This relationship shows that ROA has a negative effect on profit sharing. While quick ratio has a positive effect, this condition shows that most of SCB still reluctant to disburse finance in profit sharing scheme. The regulator should motivate them to give more profit sharing scheme.

\section{Suggestions}

For further research, the longer period should be added. Other than that, another observation object could be added like a rural bank. Since the growth of sharia rural bank is also significant.

\section{REFFERENCES}

Abdillah, D. (2014). Kinerja Perbankan Syariah Indonesia Ditinjau dari Maqasid Syariah: Pendekatan Syariah Maqasid Index (SMI) dan Profitabilitas. Skripsi. Universitas Islam Negeri Sunan Kalijaga. https://doi.org/ 10.1017 / CBO978110741 5324.004

Adzhani, R., \& Rini. (2017). Komparasi kinerja perbankan syariah di Asia dengan pendekatan maqasid syariah. Jurnal Akuntansi dan Keuangan Islam, 5(1), 5-30. Retrieved from: https://jurnal.sebi.ac.id/ index.php/jaki/article/view/ $73 / 62$
Afrinaldi. (2014). Analisa kinerja perbankan syariah Indonesia ditinjau dari maqasid syariah: Pendekatan syariah maqasid index (SMI) dan profitabilitas bank syariah. Islamic Economic $\mathcal{E}$ Finance (IEF) Universitas Trisakti, 24(1), 24-52.

Antonio, M. S., Sanrego, Y. D., \& Taufiq, M. (2012). An analysis of Islamic banking performance: Maqashid index implementation in Indonesia and Jordania. Journal of Islamic Finance, 1(1), 12-29.

Bank Indonesia. (2007). Surat Edaran No.9/24/DPbS Perihal: Sistem
Penilaian Tingkat Kesehatan Bank Umum Berdasarkan Prinsip Syariah. 53(9), 1689-1699. https://doi.org/10.1017/ CBO9781107415324.004

Basher, S. A., Kessler, L. M., \& Munkin, M. K. (2017). Bank capital and portfolio risk among Islamic banks. Review of Financial Economics, 34, 1-9. https:/ / doi.org/ 10.1016/j.rfe.2017.03.004

Bougatef, K., \& Korbi, F. (2018). The determinants of intermediation margins in Islamic and conventional banks. Managerial Finance, 44(6), 704-721. https:/ / doi.org/10.1108/MF-11-20160327 
Chapra, U. (2011). Visi Islam dalam Pembangunan Ekonomi: Menurut Maqasid Asy-Syariah. P. I. A. Basri, Edition. Solo: AlHambra.

Dusuki, A. W., \& Abdullah, N. I. (2015). Maqasid al-shari'ah, maslahah, and corporate social responsibility. The American Journal of Islamic Social Sciences, 24(1), 25-45. http://www.sims. edu/wp-content/uploads / 2015/04/JIDNYASA.pdf

Erol, C., Baklaci, H. F., Aydoðan, B., \& Tunç, G. (2014). Performance comparison of Islamic (participation) banks and commercial banks in Turkish banking sector. EuroMed Journal of Business, 9(2), 114-128. https://doi.org/ 10.1108/EMJB-05-2013-0024

Hamza, H. (2015). Does investment deposit return in Islamic banks reflect PLS principle? Borsa Istanbul Review, 16(1), 32-42. https:// doi.org/10.1016/ j.bir.2015.12.001

Mejia, A. L., Aljabrin, S., Awad, R., Norat, M., \& Song, I. (2014). Regulation and supervision of Islamic banks. IMF Working Papers, 1-33. https://doi.org/ 10.1057/jbr.2012.3
Minhat, M., \& Dzolkarnaini, N. (2016). Islamic corporate financing: Does it promote profit and loss sharing? Business Ethics, 25(4), 482-497. https://doi.org/ 10.1111/beer. 12120

Mohammed, M. O., \& Razak, D. A. (2008). The performance measures of Islamic banking based on the maqasid framework. IIUM International Accounting Conference (INTAC IV), 1-17.

Mohammed, M. O., Tarique, K., \& Islam, R. (2015). Measuring the performance of Islamic banks using maqâcid -based model. Intelectual Discourse, 4878(SI), 401-424.

Pradesyah, R. (2017). Analisis pengaruh non performing loan, dana pihak ketiga, terhadap pembiayaan akad mudaraba di bank syariah. Jurnal Agama dan Pendidikan Islam Intiqad, 9(1), 93-111.

Ratnaputri, W. (2013). The analysis of Islamic bank financial performance by using CAMEL and shariah conformity and profitability. Jurnal Dinamika Manajemen, 4(2), 220-232.

Rusydiana, A. S., \& Parisi, S. Al. (2016). The measurement of Islamic bank performance: A study using maqasid index and profitability. Global Review of Islamic Economics and Business, 4(1), 1-14.

Sarker, A. A. (2006). CAMELS rating system in the context of Islamic banking: A proposed " $\mathrm{S}$ " for shariah framework. Journal of Islamic Economics, Banking, and Finance, 2(2), 1-26.

Sutrisno. (2017). Pengukuran Kesehatan bank syariah dengan sharia compliance and performance. Jurnal Keuangan dan Perbankan, 21(40), 133-143.

Triyuwono, I. (2011). ANGELS: Sistem Penilaian tingkat kesehatan (TKS) bank syari'ah. Jurnal Akuntansi Multiparadigma, 2(1), 1-21.

Yudaruddin, R. (2017). The global economic crisis and its impact on Indonesia's education. Jurnal Keuangan dan Perbankan, 21(4), 621-629.

Yulianto, A., \& Solikhah, B. (2016). Investigate the influence factors of mudharaba financing to strengthen the core bussines of islamic banking. International Journal of Applied Business and Economic Research, 14(5), 30253034. 